\title{
Development of a freshness sensor with flavin-containing monooxygenase
}

\section{フラビン含有モノオキシゲナーゼを用いた鮮度センサの開発}

\author{
Kazuhisa YANO, Yohei KUBOTERA, Yuki HASHIMOTO, Kohji MITSUBAYASHI \\ Dept. of Human and Information Science, Tokai University, 1117 Kitakaname, Hiratsuka, Kanagawa, 259-1292, Japan. \\ TEL: +81-463-58-1211(ext. 4161) FAX: +81-463-59-4014 \\ Takeshi YOSHIKAWA, Yoshitake NISHI \\ Dept. of Materials Science, Tokai University, 1117 Kitakaname, Hiratsuka, Kanagawa, 259-1292, Japan. \\ TEL: +81-463-58-1211(ext. 4206) FAX: +81-463-50-2096 \\ Hideaki ENDO
}

Dept. of food science and technology, Tokyo University of fisheries, 5-7, Konan 4, Minato-ku, Tokyo 108-8477, Japan. TEL: +81-3-5463-0616 FAX: +81-3-5463-0616

(Received 19, November 2001 Accepted 26, July 2002)

\begin{abstract}
A freshness sensor for fish and meat was constructed by immobilizing flavin containing monooxygenase type-3 (FMO3) as, one of drug metabolizing enzymes in human liver, to a dissolved oxygen electrode. The FMO3 immobilized sensor was calibrated against trimethylamine solutions (TMA, fish-odor substance) from 1.0 to $50.0 \mathrm{mmol} / \mathrm{l}$. As the results of the experiments with fish and meat samples, the sensor output increased by increasing a keeping period at the room temperature for their decomposition.
\end{abstract}

Keywords: freshness sensor, trimethylamine, methyl mercaptan, flavin-containing monooxygenase

\section{INTRODUCTION}

魚肉や畜肉の鮮度評価は、品質や加工工程の管理にお いて不可欠であり、迅速な鮮度の測定が求められている。 これまで鮮度評価には、 $\mathrm{K}$ 值、生菌数等が測定されてき たが、これらの測定法は操作が煩雑で計測に時間を要す る等の問題があり、より簡便で短時間に魚肉・畜肉の鮮 度を測定することのできるセンサが望まれている。1,2

一般に、海産物や畜肉ではその死後、微生物の増殖に ともなう腐敗により、海産物ではトリメチルアミン (TMA)が、また畜肉ではメチルメルカプタン(MM)が急速 に増加し、腐敗臭として放出される ${ }^{3}$ 。このことから、こ の臭気成分を分析することで魚肉・畜肉を非破壊にて鮮 度評価できるものと期待されている。

本研究では薬物代謝酵素であるフラビン含有モノオ キシグナーゼ 3 を用い生鮮食品の腐敗にともなう代謝産 物(TMA・MM)を検出する「魚肉・畜肉用鮮度センサ」を 開発し、実際に抽出サンプル溶液による魚肉・畜肉の鮮 度評価に適用した。

\section{EXPERIMENTAL}

薬物代謝酵素の 1 つである FMO3(Human flavincontaining monooxygenase type-3 (FMO3); from Adult human liver; E.C.1. 14.13.8, P233, 30200pmol $/ \mathrm{mg} \cdot \mathrm{min}$, Gentest Corporation., MA, USA)は次式の反応に従い TMA

$$
\mathrm{S}+\mathrm{NADPH}+\mathrm{H}^{+}+\mathrm{O}^{2} \stackrel{\mathrm{FMO} 3}{\longrightarrow} \mathrm{SO}+\mathrm{H}_{2} \mathrm{O}+\mathrm{NADP}^{+}
$$

$\mathrm{S}:$ Trimethylamine, Methyl Mercaptan

をトリメチルアミンオキサイド(TMAO)へと、また MM を 2 硫化ジメチルへの酸化反応を触媒する。 4,5

実験ではFMO3 を用い酵素センサを作製した。酵素固 定化膜はあらかじめ洗浄、乾燥させておいた透析膜 (Dialysis membranes; 157-0144-02, thickness $15 \mu \mathrm{m}$, Technicon Chemicals Co., S.A.)に、FMO3 と光架橋性樹脂 (PVA-SbQ; SPP-H-13(Bio), Toyo Gosei Kogyo Co., Ltd., Tokyo, Japan)の混合液(重量比 1:3)を狳布し、蛍光灯照射 による光架橋にて酵素を包括固定することにより FMO3 固定化膜を作製した。

$\mathrm{FMO} 3$ 固定化バイオセンサの構成を Fig.1 に示す。 FMO3 固定化膜を市販のクラーク型酸素電極(oxygen sensor; Able Co., Ltd., Tokyo, Japan.)の感応部にナイロン ネットとシリコンO-リングを用いて装着し、FMO3 固定

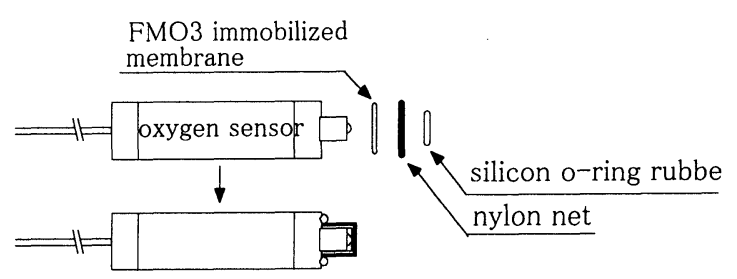

Fig. 1. Structure of a freshness sensor. 
化バイオセンサとした。

実験では、フローインジェクション実験系を用い、 FMO3 固定化センサを組み込んだ反応セルにリン酸緩衝 液をペリスタポンプにより送液し、そこへ TMA 溶液ま たは魚肉・畜肉のサンプル溶液をシリンジ(Hamilton Microliter Syringes,TYPE;710,Hamilton Company, USA)に てインジェクションし、FMO3 の酵素反応にともなう溶 存酸素の減少を酸素電極にてとらえ、そのセンサ出力を ポテンシオスタット、A/D 変換機を介して計測した。

次に、魚肉(アジ)・畜肉(ハム)の抽出液を用いて鮮度評 価を行った。抽出液の作製は、まず、室温 $\left(25^{\circ} \mathrm{C}\right)$ にて放 置したアジと八ムより適宜取り出した筋肉をリン酸緩 衝液にて 10 倍希釈し、乳鉢にてホモジナイズした懸濁 液を 2 時間の遠心分離操作を 2 回行い、その上澄み液を 計測に用いた。実験は、上記のフローインジェクション 系を用いた。

\section{III.RESULTS AND DISCUSSION}

TMA 標準溶液をインジェクションした際の忘答およ び再現性を Fig.2 に示す。実験の結果、TMA 標準液のイ ンジェクションにともなうセンサ出力の増加が観察さ れ、インジェクション後の反応ピーク值までの応答時間 は約 30 秒であった。

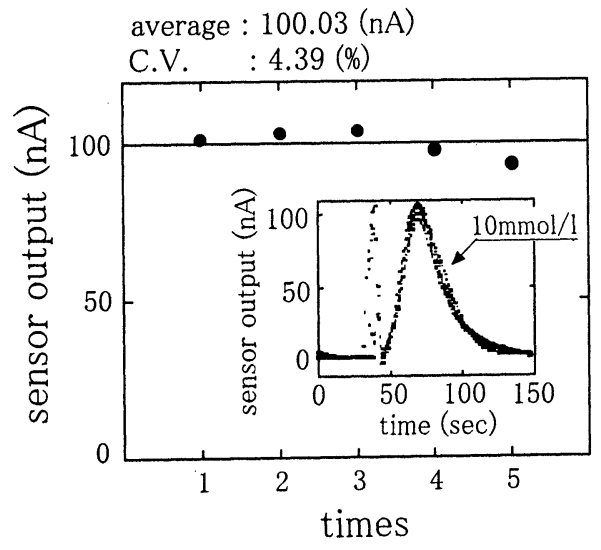

Fig.2. Responses and reproducibility of the freshness sensor.

インジェクション法により得られた本センサの検量 特性を Fig.3 に示す。実験の結果、TMA 標準溶液を 1-50 $\mathrm{mmol} / \mathrm{l}$ の範囲で定量が可能であることが確認できた。

魚肉および畜肉の放置時間にともなうセンサ出力の 変化を Fig.4 に示す。この図に示すように、魚肉の放置 時間にともないセンサ出力が急激に増加しており、この ことから魚肉内における腐敗にともないTMA 等の 2 級、 3 級アミンが急激に増加したものと考察された。また、 畜肉においても魚肉同様、保存時間にともなうセンサ出

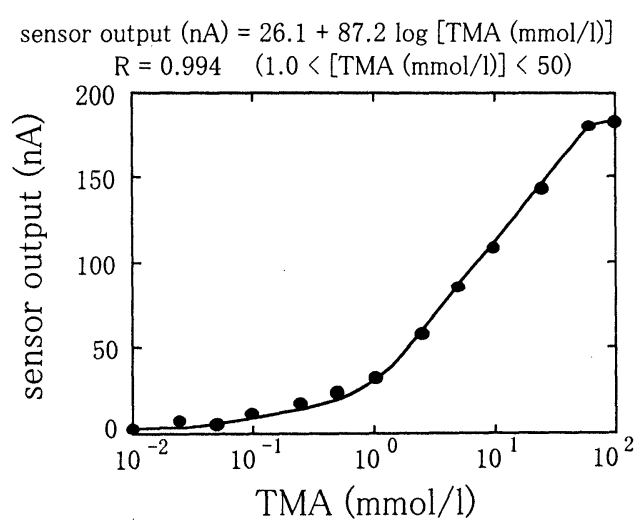

Fig. 3. Calibration curve for TMA in the liquid-phase. 力の増加が観察され、畜肉の腐敗にともない $\mathrm{MM}$ 等の硫 黄化合物が増加したものと考察された。

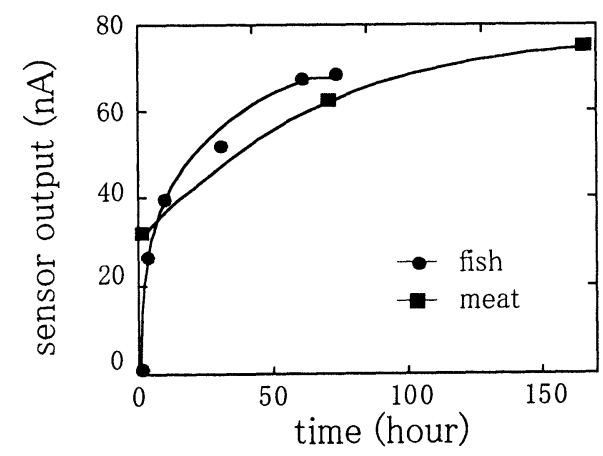

Fig. 4. Change in the sensor output for extract fish and meat.

\section{CONCLUSION}

本研究では、生体の肝臟に存在する薬物代謝酵素の一 つであるFMO3を用いることで、新規な魚肉・畜肉用の 鮮度センサを開発した。既存の多成分分析による方法と 異なり、本センサ方法では魚肉・畜肉の腐敗にともない 発生する $\mathrm{TMA} \cdot \mathrm{MM}$ を腐敗評価の単一指標とすることで、 簡便かつ迅速に評価することができた。

またこれら指標成分が揮発性を有することから、本セ ンサを用いたガス計測により、腐敗臭気による非破壊法 による鮮度評価の可能性も示唆された。

\section{REFERENCES}

1 E. Watanabe, Chemical and Biology (in Japanese), 38(3), (2000), 171

2 T. Saito, K Arai, M. Matsuyoshi, Bulletin of Japanese Society of Scientific Fisheries, 24, (1959), 749

3 The Environmental Agency in Japan, A legal book for malodorant (in Japanese), (1993), 414

4 R. Kato, T. Kamataki, Comparison Biochemistry of drug metabolizing (in Japanese), (1983), 277

5 M. Ohki, T. Ohsawa, M. Tanaka, et.al., chemistry dictionary, (1996), 2325 